\title{
Siberia in the Mirror of Other Cultures: Literature and Translation
}

\author{
Veronica A. Razumovskaya* \\ Siberian Federal University \\ 79 Svobodny, Krasnoyarsk, 660041, Russia
}

Received 24.06.2015, received in revised form 14.07.2015, accepted 19.09.2015

The article deals with the origin and the matter of reflecting the "Siberia" concept in the texts of Russian literature, which has resulted in the creation of a "strong" literary image of Siberia. The particular attention is paid to the Siberian text as a translation object and to translation units in the text. The article considers the main types of Siberian texts involved in the interlingual literary translation: tales and epic texts of the peoples of Siberia, literary texts of Siberian writers (V.P Astafyev, V.M. Shukshin). The Siberian text is understood as an integral and significant part of the Russian cultural and literary space. Being involved in the continuous process of global cross-cultural interaction and mutual influence, the Siberian text broadcasts cultural information about Russia and Siberia to the representatives of "other" cultures.

Keywords: : Siberia, Siberian text, literary image, literary translation, culturonym.

DOI: 10.17516/1997-1370-2015-8-12-2939-2946.

Research area: philology.

In the perception of the representatives of "other" cultures, Russia is traditionally associated with such key concepts as "vast territory", "multinational", "multilingualism" and "multiculturalism". Conceptual heterogeneity is a direct consequence of the fact that different Russian territories have geographical, historical and cultural peculiarities. Siberia occupies a special place among the territories of Russia.

The etymology of the toponym "Siberia" is unclear (Turkic, Mongol or Tatar). It was first mentioned in the chronicles of the $12^{\text {th }}$ $13^{\text {th }}$ centuries (Pospelov, 2001). In 1821, the Decembrist K.F. Ryleev wrote in his ballad
"The Death of Ermak" (the verse part of which has later become the folk song "The storm was roaring"): "The word Siberia now means an immeasurable space from the Ural mountain range to the shores of the Eastern Ocean. In the old days, the Siberian kingdom was the name of a small Tatar property, with its capital Isker on the Irtysh River, a tributary of the Ob" (Ryleev, 2013: 207). Currently, the lexical unit "Siberia" has several meanings: the northern part of Asia; a vast geographical area of the north-eastern Eurasia limited by the Ural Mountains, the dividing ridges of the Pacific Ocean, the Arctic Ocean and the borders of neighbouring states

(C) Siberian Federal University. All rights reserved

* Corresponding author E-mail address: veronica_raz@hotmail.com 
of Russia (Kazakhstan, Mongolia and China); a historical concept, which also includes the northeast of Kazakhstan and the Far East of Russia. It is believed that the first use of the word "Siberia" for the geopolitical purpose to refer to the territory lying to the east of the Volga can be found in the letter of the Russian Tsar Ivan the Terrible to the English Queen Elizabeth I dated 1570 (Grozny, 2000). It was during the reign of Ivan the Terrible when the multinational Siberian Khanate was annexed to the Moscow state, and Siberia for a long time had become a colony with the increase in population due to migration of peasants, as well as people in exile and convicts. Modern Siberia occupies $73 \%$ of the territory of Russia, and its area without the Far East exceeds the total area of Canada. The population of Siberia is about 26 million people, accounting for $18 \%$ of the total population of Russia. Siberia is a very underpopulated area (2 people per 1 square $\mathrm{km}$ ). In 2000, the Siberian Federal District was formed on the territory of Siberia under the Presidential Decree (19 million residents). The vast territory of Siberia, its historical, climatic and demographic features, as well as rich reserves of various minerals determine the importance of the region in the political, economic and, of course, cultural life of Russia.

The concept "Siberia" conceptualized in the Russian language in the process of development of the vast Siberian territories that may be considered, for example, on the material of the texts of peasant petitions (chelobitnaia), reflecting the linguistic consciousness of the authors (Iniutina, 2015). The "strength" of the concept "Siberia" in the cultural space of Russia creates numerous cultural stereotypes and results in the regular reflection of this concept in literary texts. This fact suggests the presence of a complex of Siberian mythologems associated with this concept, and the literary image of Siberia (Tiupa, 2002, Ertner).
One of the first literary works depicting the image of Siberia was "The Life of the Archpriest Avvakum" written in the $17^{\text {th }}$ century. Exiled to Tobolsk, and then to the Trans-Baikal for his opponent views concerning the reforms of Nikon, the archpriest described Siberia as a space of infinite cold, constant hunger and terrible human sufferings. It is noteworthy that in this text, there is a steady opposition "Russia (Rus') - Siberia". The idea of Siberia as a kind of the "other", "non-Russian" land is very strong in the Russian literary tradition. "Even Siberians themselves treated Siberian margins as completely opposite: from the notion that "Siberia is the same Russia" to the absolute identity of Siberia and formation of special "Russian Siberian peoples" here" (Shakherov, 2004: 19). Initially Siberia is understood in literary texts only as an extremely remote and dangerous area, which is directly related to the stable association of Siberia as a traditional place of exile almost during all periods of the history of the Russian state since the exploration of the territory by Ermak. It was Siberia that became the place of exile for Decembrists. Investigating the way of life of the exiled Decembrists, Yu.M. Lotman notes that due to the steady negative associations Siberia has entered "literary themes and oral mythology of the Russian culture as a place of exile" (Lotman, 1994: 113). A striking image Siberia-prison for the Decembrists was created by A.S. Pushkin in his famous poem of 1827 "In the depths of the Siberian ores ...". The image of Siberia as a place of exile is represented in the texts of many Russian classics: A.N. Radishchev, A.S. Griboyedov, N.V. Gogol, V.G. Korolenko, F.M. Dostoevsky (Khlamova, 2009). Although the Siberian land became the place of exile of the Decembrists, literary writing of many of them marked the beginning of the creation of a positive image of Siberia (Nikonov). 
Thus, the toponym "Siberia" has got not only the stable associations with such concepts as "exile" and "prison", but also possesses the associations with the concepts "exotics", "wealth", "freedom". For A.P. Chekov Siberia is primarily "the road" as the writer travelled from Moscow to Sakhalin via vast territory of Siberia. And it was Chekov who predicted the future of the Siberian land: "I stood there and thought what a overwhelming, intelligent and courageous life will illuminate these banks in course of time" (Chekov, 1978: 35). The new meaning of "the land as fairy tale" was presented in a number of texts by N.A. Nekrasov. Later the idea of fabulous and fantastic Siberia (which is very close to mythological mentality) was found in literary texts.

There is no doubt that a special place in Siberian studies belongs to the Siberian text, understood in this paper, in the broad sense as a text "about Siberia" (Anisimov, 2010: 3). According to A.S. Ianushkevich, this kind of the text was formed in the process of exploring Siberia as a special semiosphere and has peculiar chronotopic and polysemantic characteristics. Defining the Siberian text as a historiosophical and historical-cultural concept, as historiosophical and cultural dichotomy, the researcher points out that in the process of understanding this concept at the intersection of both myth and reality, the Siberian text inside and outside acquires the energy of identification and self-consciousness. It is highly important that Siberian literature and, accordingly, Siberian culture had not been developing in isolation from Russian literature and culture. Thus, the evolution of the Siberian text and, respectively, Siberian literature from the end of the $18^{\text {th }}$ century until the beginning of the $20^{\text {th }}$ century allows A.S. Ianushkevich to come to the conclusion that the interaction with Siberian literature enriches Russian literature with new material and expands its anthropological space.
Siberian and Russian literature are inseparable "But may be Siberian literature was an organic part of the whole of Russian culture? ... And later on, literary discoveries of Vampilov and Shukshin, Astafyev and Rasputin will spread in the text of the all-Russian literary process and will determine something very significant in its development" (Ianushkevich, 2004: 234).

Therefore, Siberian and Russian literature and culture, recognizing the great conditionality of this distinction, are closely interrelated and interdependent and jointly participate in the international literary and cultural process. A special place and a special role in this process belongs to the literary translation, an effective instrument for the exploration of the world, formation and expansion of the cultural memory of humanity and, without any doubt, a cultural phenomenon. In the translated versions the Siberian literary text finds its reflection in the mirrors of other cultures and participates in the dialogue of cultures understood as "cognition of other cultures through one's own culture and one's own culture through other cultures by means of cultural interpretation and adaptation of these cultures to each other" (Mironov, 2005: 150).

An important place among Siberian literary texts belongs to the texts of fairy tales. In 1935, "The Northern Tales" of the famous collector of folklore, M.I. Osharova, were published. The edition includes more than a hundred tales of the indigenous peoples of the northern territories of Siberia (Evenks, Kets, Dolgans and Nenets). In the ten-volume edition of 1995, "The Tales of the World Folks", the tales of the Siberian peoples are represented in the tenth volume. "The Tales of the Peoples of Siberia" were published in 1884 in Novosibirsk. The publication "The Tales of the Peoples of Siberia" of 1992 deserves special attention. The book is organized on the principle of parallel texts and includes Russian fairy tales and Russian texts of the fairy tales of Tuvans, 
Evenks, Selkups, Dolgans, Yakuts, Tofalars, Kets, Buryats, Mansi, Nenets, Nanai and Nganasans, as well as English translations of the texts of fairy tales (Tales, 1992).

The acquaintance of the Russian reader with the literary works of the peoples of Siberia is due to an outstanding contribution made by A.V. Prelovsky. The writer, poet and translator made numerous translations of the folk tales from Yakut, Buryat, Yukaghir, Khakass and other languages of the peoples of the multinational Siberia into Russian (Prishchepa, 2012). In the works by A.V. Prelovsky his activity of a writer was combined with the activity of a translator, "the practice of translation, especially the translations of the poetry of the peoples of Siberia, for many years has been happily combined with my own lyrical practice without interfering, but enriching it" (Prelovsky, 1984: 9). It is noteworthy that A.V. Prelovsky translated not only the texts of contemporary Siberian ethnic groups, but also the texts of ancient Turkic poetry.

The traditional object of translation from the category of literary texts of the peoples of Siberia are the texts of the Olonkho, a heroic epic tale of the Yakuts performing a number of functions: culture preserving, sacred, educational and entertaining. The Olonkho accumulates spiritual values of the Yakuts, reflects the historical and social experience, beliefs of the people, the historical and cultural memory. In 2000 the epic celebrated 1,250 years of its origin. The researchers said that the Yakut epic incorporates many encoded elements of the spiritual heritage of the ancient cultures of Eurasia, ranging from the Neolithic to the late Middle Ages (Vasil'ev, 2001). In 2005 UNESCO recognized the Olonkho as a masterpiece of the Oral and Intangible Heritage, also due to the hard work of translators.

The first experiments of translating the Olonkho (into Russian) were made simultaneously with the recording of the Yakut original texts. Thus, in 1851, O.N. Betling for the first time publishes the Olonkho text with the German interlinear translation. N.S. Gorokhov and R.K. Maak publish the Olonkho texts they recorded and Russian translations in 1884 and in 1887 respectively. A well-known translator of the Olonkho into Russian in the first third of the $20^{\text {th }}$ century was the Yakut bilingual poet P.N. Chernykh-Yakutsky (Rufova, 2011). Historiography of Russian translations of the Olonkho includes translations of S.V. Iastremsky, G.U. Ergis, I.V. Pukhov and V.V. Derzhavin.

From 1980 the development of the Yakut language translation into foreign languages begins. The key objects of translation into foreign languages are the Olonkho epic texts. The first translator of the Olonkho into French was Yankel Karro, a staff member of the National Library in Paris, who opened the wonderful world of the ancient Yakut epic to the European reader by translating the Olonkho "Nurgun Botur the Swift" of K.G. Orosin into French in 1990. In the preface to the edition of the French translation, a famous expert in Turkic studies Louis Bazin wrote that "... the great epic poem "Nurgun Botur" is one of the most representative to understand the ideas of the world and supernatural powers of the Siberian peoples; it is impregnated with the original shamanistic faith" (Bazin, 1994). Some epic texts were for the first time translated into English and published in 1971 by Douglas Lindsay. The US researcher suggested a prosaic version of the translation of the Olonkho "Er Sogotokh" (Douglas Lindsey. "Er Sogotokh: The Lone Stranger"). Koehiro Yamashita and Ogawa Makasuni translated a number of texts of the Olonkho into Japanese. There are other translations of fragments of the Olonkho "Nurgun Botur the Swift" of P.A. Oiunsky into French (translated by J. Carro, L.M. Sabaraikina), into English (translated by A.A. Scriabina in 1993 and R.Iu Skrybykin in 1995). In 2002 in the 
Republic of Sakha-Yakutia a multilingual project of translation the Olonkho "Eles Botur" into the English language was launched by P.V. Ogotoev (the translator A. Scriabina). There are translations of the Olonkho into German and Korean. In 2007, the Institute of World Philology and Regional Studies of the NEFU (the University centre of the Olonkho translations into foreign languages) initiated the project of translating the fundamental work of P.A. Oiunsky "Nurgun Botur the Swift" into English under the State target programme on the preservation, study and dissemination of the Yakut heroic epic Olonkho (2006-2015). In 2010, a new version of the translation of the Olonkho of P.A. Oiunsky into Russian language appeared (the translator E.S. Sidorov). One of the recent English translations of the Olonkho "Nurgun Botur the Swift" of K.G. Orosin into English is the version of A.A. Nakhodkina (2008). A significant milestone in the translation of the Olonkho texts into foreign languages became publishing of the English translation of "Nurgun Botur the Swift" of P.A. Oiunsky by the Renaissance Books British publishing house in 2013. The publication was dedicated to the $120^{\text {th }}$ anniversary of birth of the author of the original text honoured as the founder of Yakut literature and the Yakut literary language in Yakutia, as well as one of the founders of the Yakut ASSR. Many foreign-language translations of the Olonkho were made indirectly (mainly from older Russian translations). Thus, the most common texts of the Yakut Olonkho translated into the languages of the world have become the heritage of the world culture and are available to representatives of "other" cultures. Coming of the national literature beyond the "national" language and cultural environment by means of translation promotes cultural interaction, interpenetration and mutual influence that provides a global cultural diversity (Khairullin, 1999).

A significant proportion of translations of Siberian literary texts belongs to the works of Siberian masters of the literary word. For example, in an article published nearly 30 years ago, it is noted that the books of S. Zalygin had been translated into 15 foreign languages, books of V. Shukshin into 18, and books of V. Rasputin into 21 language of the world (Zinov'eva, 1987). The data are presented excluding the translation into the languages of the peoples of the Soviet Union, which may be the subject of a special investigation. It is noteworthy that less than twenty works by V. Shukshin have been already translated into 26 languages (Mar'in, 2004).

Literature experts unanimously note that V.P. Astafyev is the most famous in the world and, accordingly, the most translatable Siberian writer. Thus, the first known foreign-language translation of Astafyev's text was the Polish translation of the novel "Falling Stars" (1960), published in 1961. By the beginning of the $21^{\text {st }}$ century the writer's works have been translated into 22 languages and published in 28 countries [Robonen 2005: 221]. The index of works published in the honour of his seventy-fifth anniversary, reports of the translations of Astafyev's texts into many European languages: Bulgarian (15), Polish (14) Czech (13), German (13) English (9), Hungarian (8), Slovak (8) French (4), Dutch (3), Finnish (3) Danish (2), Spanish (2), Romanian (2) Swedish (2) Norwegian (1) [Viktor Astafyev 1999]. According to the Index Translationum World translation database created by UNESCO in 1932, the works of V.P. Astafyev have been also translated into Japanese (1983), Arabic (1990), Vietnamese (1990), Frisian (1989), Breton (1998) and Chinese $(1982,1985,1995,1997)$ languages as well as into the languages of the peoples of the former Soviet Union - Turkmen (1979), Armenian (1979), Kyrgyz (1980, 1985), Latvian (1980, 1988), Tatar (1980, 1983, 1986), Estonian (1981, 1983, 1984, 1986, 1988) Moldovan (1982), Georgian (1982, 1988), Lithuanian (1985, 1989), 
Kazakh (1985, 1988), Ukrainian (1986, 1987, the cultural identity and literary features of the 1990), Belarussian (1992).

Therefore, we can assert that literary works of V.P. Astafyev are under scrutiny of the translators of not only Western countries, but also countries of the East. For example, the following works have been translated into Chinese: "Shepherd and Shepherdess" (translated by Xia Zhunyi), "The King Fish" (translated in 1982 by a group of translators headed by Xia Zhunyi), "Falling Stars" (translated in 1985 by Feng Yuli), "The Sad Detective" (translated in 1989 by Yu Yizhong), "Zatesi", "The Ode to the Russian Garden" (translated in 1995 by Chen Shuxian and Zhang Dabeng), as well as a number of stories.

Translators of the Siberian text are unanimous in recognizing their main task as preserving original in the secondary translated text. The success of sharing Siberian culture with other cultures depends on the accuracy and correctness of the allocation of translation units in the original text, selection of the most effective strategies for the transfer of culturally marked units of translation involving cultural preservation or cultural substitution. A special challenge for translators is the transfer of exotic words, proper names and linguistic identity of the authors of the texts and their characters. Recognizing the objective and subjective difficulties of translation of Siberian literary texts, it should be noted that the Siberian text expands its presence in the global cultural space and enables representatives of "other" cultures to get acquainted with Siberian cultural peculiarities.

\section{References}

Anisimov, K.V. Ot redaktora [Editor's Word]. Sibirskii tekst $v$ natisonal'nom siuzhetnom prostranstve [Siberian Text in the National Subject Space]. Krasnoyarsk: Siberian Federal University, 2010, p. 3-6.

Bazin, L. Preface. Les guerriers célestes du pays Yakoute-Saxa: Elleï, son origine, sa descendance, Niourgoun le Yakoute, guerrier céleste, Grand Koudansa, le présomptueux. Translated by Yankel Karro and Lina Sabaraikina. Paris, Gallimard, 1994, p.1-7.

Chekhov, A.P. Iz Sibiri [From Siberia]. Full Collection of Works and Letters in Thirty Volumes. Vol. 14-15. Moscow, Nauka, 1978, p. 5-38.

Ertner, E.N. Obraz Sibiri v russkoi literature XIXv. [The Image of Siberia in Russian Literature of the $19^{\text {th }}$ century]. Available at: // http://utmn.ni/No6/text16.htm

Grozny Ivan IV [Ivan the Terrible IV]. Works. St. Petersburg, Azbuka, 2000. 245 p.

Ianushkevich, A.S. Sibirskii tekst: vzgliad izvne i iznutri [Siberian Text: the Look from the Outside and the Inside]. Sibir': vzgliad izvne i iznutri. Dukhovnoe izmerenie prostranstva [Siberia: The Look from the Outside and the Inside. Spiritual Measurement of the Space]. Irkutsk, 2004, p. 227-235.

Index Translationum [Online] Available at: http: // www.unesco.org/xtrans/bsstatexp.aspx (July 12, 2015).

Iniutina, L.A. (2015). Poniatie sibirskogo prostranstva v tekstakh, otrazhziushchikh iazykovoe soznanie XVII-XVIII vekov [The Concept of Siberian Area in the Texts Reflecting the Linguistic Consciousness of the $17^{\text {th }}-18^{\text {th }}$ centuries]. INTEREKSPO GEO-SIBIR, 2(6), 71-74.

Khairullin, V.I. (1999). Kul'tura v paradigm perevodovedeniia [Culture in the Paradigm of the Translation Studies]. Tetradi perevodchika [Translator's Notebooks], 24, 38-44. 
Khlamova, A.M. (2009). Ugolovanaia ssulka v Sibir' v khudozhestvennom diskurse Rossii vtoroi poloviny XIX veka [The Criminal Exile to Siberia in theLiterary Discourse of Russia in the Second Half of the $19^{\text {th }}$ Century]. Omskii nauchny vestnik [Omsk Scientific Bulletin, 5(81), 33-37.

Lotman, Yu.M. Dekabrist v povsednevnoi zhizni (bytovoe povedenie kak istorikopsikhologicheskaia kategoriia) [The Decembrist in the Everyday Life (Everyday Life Behaviour as a Historical-psychological Category)]. Besedy o russkoi kul'ture: Byt i traditsii russkogo dvorianstva (XVIII-nachalo XIX veka) [Talks about the Traditions of Russian Nobility (the $18^{\text {th }}$ - beginning of the $19^{\text {th }}$ century)]. St. Petersburg, Iskusstvo-SPb, 1994, p. 101-168.

Mar'in, D.V. Filologicheskii metod predstavleniia perevoda sekventsii tekstov. Na material sbornika perevodov rasskazov V.M. Shukshina "V. Shukshin. Stories from a Siberian village" [The Philological Method of Presenting the Translation of the Sequence of Texts. On the Materials of the Collection of Translations of V.M. Shukshin's Stories "V. Shukshin. Stories from a Siberian village"]. Thesis of the PhD of Philology. Kemerovo, 2004. 255 p.

Mironov, V.V. Filosofiia i metamorfozy kul'tury [Philosophy and Metamorphoses of Culture]. Moscow, Sovremennye tetradi, 2005. 424 p.

Nikonov, N.B. Izobrazhenie Sibiri v russkoi literature i publitsistike v pervoi polovine XIX veka [The Image of Siberia in Russian Literature and Social and Political Journalism in the First Halv of the $19^{\text {th }}$ Century]// Available at: http://dorogiistorii.ru/nauchnie-i-nauchno-populyarnie-izdaniya/nikonovn-b-izobrazhenie-sibiri-v-russkoy-literature-i-publitsistike-v-pervoy-polovine-xix-veka.html

Pospelov, E.M. Geograficheskie nazvaniia mira. Toponimicheskii slovar' [Geographic Names of the World. The Toponymic Dictionary]. Moscow, AST, 2001. 512 p.

Prelovsky, A.V. Avtobiogrqaficheskie zametki [Autobiographic Notes]. Selected Works. Verses and Poems. 1955-1981. Moscow, Khudozhestvennaia literature [Fiction], 1984, p. 3-27.

Prishchepa, V.P. (2012). Problemy i prichiny obrashcheniia A.V. Prelovskogo k khudozhestvennomu perevodu tekstov sibirskikh natsional'nykh poetov [Problems and Reasons that Have Influenced A.V. Prelovsky to Turn to the Literary Translation of the Texts of Siberian National Poets]. Mir nauki, kul'tury, obrazovaniia [The World of Science, Culture and Education], 1, 351-353.

Robonen, E.V. Mezhdunarodnye sviazi V.P. Astaf'eva [International Relationships of V.P. Astafyev]. Fenomen V.P. Astaf'eva v obshchestvenno-kul'turnoi i literaturnoi zhizni kontsa XX veka [The Phenomenon of V.P. Astafyev in the Social, Cultural and Literature Life of the End of the $20^{\text {th }}$ Century]: Collection of Materials of the I International Scientific Conference Devoted to the Creative Work of V.P. Astafyev. Krasnoyarsk, September 7-9, 2004. Krasnoyarsk State University, 2005, p. 221-225.

Ryleev, K.F. Smert' Ermaka [The Death of Ermak]. Kak schastliv ia! [I am so happy!]. Moscow, Komsomol'skaia Pravda; NeksMedia, 2013, p. 207-209.

Rufova, E.S. Tvorchestvo P.N. Chernykh-Iakutskogo v kontekste literaturnogo protsessa Iakutii nachala XX veka [The Works of P.N. Chernykh-Yakutsky in the Context of the Literary Process of Yakutia at the Beginning of the $20^{\text {th }}$ Century]: Author's Abstract of the Thesis of the PhD in Philology: 10.01.02. Yakutsk, 2011. 23 p.

Shakherov, V.P. Vzaimodeistvie tsivilizatsii kak factor formirovaniia sotsiokul'turnogo prostranstva Aziatskoi Rossii [The Interaction of Civilization as a Factor of Formation of the Sociocultural Space of Asian Russia]. Sibir': vzgliad izvne i iznutri. Dukhovnoe izmerenie prostranstva 
[Siberia: The Look from the Outside and the Inside. Spiritual Measurement of the Space]: International Scientific Conference. September 24-26, 2004. Irkutsk, Scientific Library of Irkutsk State University, 2004, p. 19-20.

Skazki narodov Sibiri [Tales of the Peoples of Siberia]. Krasnoyarsk, Vital, 1992. 207 p.

Tiupa, V.I. (2002). Mifologema Sibiri: $k$ voprosu o "sibirskom tekste" russkoi literatury [The Mythologem of Siberia: to the Issue of the "Siberian Text" of Russia Literature]. Sibirskii filologicheskii zhurnal [Siberian Journal of Philology] , 1, 27-35.

Vasil'ev, V.E. (2001). O triade "Kuznets-shaman-voin" [About the Triade "Blacksmith-ShamanWarrior"]. Ilin, 2, Pp. 47-51.

Viktor Petrovich Astafyev: Zhizn' i tvorchestvo: ukazatel' proizvedenii pisatelia na russkom i inostrannykh iazykakh: literature o zhizni i tvorchestve [Viktor Petrovich Astafyev: Life and Works: the Index of the Writer's Works in the Russian and Foreign Languages: Literature About Life and Creative Activity] Moscow, Pashkov Dom, 1999. 240 p.

Zinov'eva, V.L. Semantika dialektnykh slov, upotreblennykh v iazyke sovremennykh sibirskikh pisatelei, i vozmozhnosti ikh perevoda na frantsuzskii iazuk [Semantics of Dialectic Words Used in the Language of Contemporary Siberian Writer and Possibilities of Translating Them into the French Language]. Leksicheskaia i frazeologicheskaia semantika iazykov narodov Sibiri [Lexical and Phraseological Semantics of the Language of the Siberian Peoples]. Novosibirsk, Institute of History, Philosophy and Philology of the SB RAS, 1987, p. 100-115.

\section{Сибирь в зеркале других культур:}

\section{художественная литература и перевод}

В.А. Разумовская

Сибирский федеральный университет

Россия, 660041, Красноярск, пр. Свободный, 79

Настоящая работа посвящена истории создания и вопросам отражения понятия «Сибирь» в текстах русской художественной литературы, что имеет своим результатом создание «сильного» художественного образа Сибири. Особое внимание уделяется сибирскому тексту как объекту перевода и единицам перевода в данном тексте. В статье рассматриваются основные типы сибирских текстов, вовлеченных в прочесс межъязыкового художественного перевода, - сказки и эпические тексты народов Сибири, художественные тексты сибирских писателей (В.П. Астафьев, В.М. Шукиин). Сибирский текст понимается как неотъемлемая и значимая часть русского культурного и литературного пространства. Будучи вовлеченным в непрерывный мировой процесс межкультурного взаимодействия и взаимовлияния, сибирский текст транслирует культурную информаџию о России и Сибири представителям «других» культур.

Ключевые слова: Сибирь, сибирский текст, художественный образ, художественный перевод, культуроним.

Научная специиальность: 10.00.00 - филологические науки. 